\title{
HUBUNGAN ANTARA PROSES PEMBELAJARAN DI MAJELIS TA'LIM AR-RIDHO DENGAN TINGKAT PEMAHAMAN AJARAN ISLAM PADA MASYARAKAT DESA CIPAYUNG DATAR RT/RW 02/03 KECAMATAN MEGAMENDUNG KABUPATEN BOGOR
}

\author{
Muhamad Khoerun \\ Universitas Ibn Khaldun Bogor
}

\begin{abstract}
This study aims to determine the relationship between the learning process in the majelis ta'lim Ar-ridho with the level of understanding of Islamic teachings in the community of Cipayung Datar Village Rt / Rw 02/03, Megamendung District, Bogor Regency. This study uses a quantitative method with a correlational approach. Sampling in this study using census techniques. Making the entire population as a sample is 50 respondents. Data collection methods namely questionnaires, data processing techniques and data analysis used validity test, normality test, reliability test. While the hypothesis testing uses the Pearson correlation statistics. The results of the normality test are in the normal category between the learning process in majelis ta'lim with the level of understanding of Islamic teachings with a sig $>0.05$. Then the results of hypothesis testing between the learning process in majelis ta'lim with the level of understanding of Islamic teachings in the community there is a moderate correlation with the Pearson correlation value of 0.579, which is significant (sig <0.05).
\end{abstract}

Keywords: Learning Process of Majelis Ta'lim, Islamic Teachings, Community Understanding

\section{PENDAHULUAN}

Dalam beberapa dekade ini, dunia Islam telah mengalami kemerosotan hingga mencapai pada tingkat yang signifikan. Perkembangan arus modernisasi dan globalisasi telah menciptakan sebuah sistem yang dapat melepas dan membebaskan manusia dari keterkaitan dirinya terhadap ajaran agama, nilai-nilai spiritualitas, adat-istiadat dan sebagainya.

Hal ini terjadi disebabkan oleh paradigma berpikir masyarakat yang keliru dalam menyikapi arus moderenisasi dan globalisasi, ditambah lagi dengan minimnya pengetahuan masyarakat dalam mengolah, memilah-milih atau menyaring/filter segala bentuk yang ditimbulkan akibat globalisasi, baik berbentuk informasi, pemanfaatan teknologi, bentuk pemahaman barat, masuknya budaya asing dan sebagainya. Sehingga sebagian masyarakat berpandangan "suka-suka gue dong, mau hidup kaya apa juga", lo gak usah ikut campur, urus aja hidup lo sendiri, jangan sok suci," dan jangan sok nyaramahin gue", dan pada akhirnya mereka merasa bebas dalam menentukan tujuan 
hidup dan nasibnya sendiri secara rasional tanpa ada ikatan agama maupun norma di masyarakat.

Selain itu pesatnya laju perkembangan ilmu pengetahuan dan teknologi juga turut membuat sebagian masyarakat lebih menekuni berbagai macam bidang, termasuk salah satu diantaranya adalah bidang keilmuan umum. Sebagian masyarakat beranggapan, bahwa dengan menempuh pendidikan umum sebanyak-banyaknya atau setinggi tingginya akan membuat kehidupan mereka mapan dan jauh lebih baik kedepanya. Akan tetapi sangat sedikit keinginan masyarakat untuk menempuh pendidikan keagamaan, yakni memperdalam pemahaman ajaran Islam. Padahal dengan memperdalam ajaran Islam kehidupan manusia akan teratur, terarah dan tentunya mereka akan berbuat sesuatu sesuai dengan rambu-rambu yang telah ditentukan oleh Islam, dan justru akan membuat kehidupan mereka akan jauh lebih baik kedepannya.

Ketidak seimbangan masyarakat dalam memperoleh pendidikan umum dan agama dimasa lalu, serta kesibukan masyarakat dalam menjalankan akatifatas sehari-hari, ditambah sangat sedikitnya masyarakat meluangkan waktu untuk memperdalam ajaran agama Islam. Juga turut mendorong timbulnya berbagai macam bentuk prilaku penyimpangan, termasuk diantaranya penyimpangan dalam menjalankan perintah syariat, karena di masyarakat pemahaman ajaran Islam hanya sebatas pengetahuan saja dalam pendidikan atau dalam peraktiknya, akan tetapi hanya sebagian masyarakat juga yang menjadikan ajaran Islam, selain sebagai pengetahuan dia juga turut mengaplikasikannya dalam bentuk pengamalan. Keadaan semacam ini nantinya akan berdampak pada rendahnya masyarakat dalam memahami ajaran Islam.

Tidak hanya itu, pola berpikir masyarakat yang masih rendah dalam memahami ajaran agama Islam, juga turut mendasari dan mendukung timbulnya berbagai bentuk penyimpangan yang masih sering dilakukan oleh masyarakat hingga saat ini diantaranya: 1. Mengabaikan dan menyepelekan perintah wajib yang sudah Allah SWT tetapkan seperti ibadah shalat, puasa, zakat, dan ibadah lainnya ditengah kesibukan yang dilakukannya. 2 . Meminta kepada orang yang sudah meninggal, 3. Masih mempercayai kebenaran hal mistis, 4. Masih berjalannya tradisi nenek moyang yang menyimpang, 5. Timbulnya syubhat (keraguan) pada dirinya, yaitu meyakini yang benar sebagai sesuatu yang bathil dan sesuatu yang bathil dianggap sebagai sesuatu yang benar, di sebabkan karena tidak mempelajari akidah shahihah secara benar. 6. Taqlid buta, yaitu mengambil pendapat manusia dalam perkara akidah dan hukum syariat tanpa mengetahui dan menelusuri seberapa jauh kebenaran dalil yang dijadikan hujjah. 7. Kemudian faktor ghuluw (berlebihan) dalam mencintai para wali dan orang salih, serta memposisikan mereka melebihi kapasitasnya, sehingga meyakini adanya unsur ketuhanan (uluhiyyah) pada dirinya. Sehingga mampu mendatangkan perlindungan, kemanfaatan, maupun menolak bahaya, dan sebagainya. (Akhmad Alim, 2014) Tidak hanya itu permasalahan yang serupa juga terjadi di Desa Cipayung Datar Rt/02 Rw/03 Kecamatan Megamendung Kabupaten Bogor, selama peneliti melakukan penelitian. Sebagaimana terlihat oleh 
peneliti yakni, masih sepinya musola dan masjid saat waktu azan berkumandang, terlihat hanya beberapa pemuda saja yang mengikuti salat berjamaah, terlihat juga masih sibuknya masyarakat dengan kegiatannya saat azan shalat berkumandang, selain itu masih rendahnya akhlak/adab sopan santun para pemuda dan remaja kepada orang yang lebih tua darinya, serta masih banyaknya pemuda dan remaja, dan santri yang masih menjalani hubungan pacaran sebelum melangsungkan akad pernikahan.

Hal demikian di atas, tentunya sangat tidak dibenarkan dalam ajaran Islam, permasalahan ini akan menjadi persoalan serius jika tidak segera diambil tindakan. Apabila dibiarkan, maka akan timbul keresahan, kebingungan dan ketidak nyamanan di kalangan umat Islam, khususnya bagi orang awam. Oleh karena itu, diperlukan langkah dan strategi tepat untuk meluruskan pengetahuan dan pemahaman masyarakat akan ajaran Islam, agar sesuai dengan tuntunan Al-Quran dan Sunah.

Adapun salah satu cara untuk mengembalikan dan meluruskan pemahaman ajaran Islam di lingkungan masyarakat yakni, melalui kegiatan pendidikan yang terdapat pada majelis ta'lim. Secara istilah Majelis Ta'lim berasal dari bahasa Arab, yakni majlis dan ta'lim. Muhmud Yunus dalam Kamus Arab-Indonesia dikutip dari (Muhsin MK, 2009) kata "majlis" berasal dari kata jalasa, yajlisu, julusan, yang artinya duduk, atau rapat. Sedangkan dalam Kamus Al-Munawwir kata "ta'lim” merupakan masdar dari kata “allama, yu'alimu dan ta'lim yang berarti mengajar atau pengajaran. (Sudarto, 2016)

Majelis ta'lim sebagai organisasi pendidikan luar sekolah, juga dikatakan sebagai lembaga pendidikan Islam nonformal bertujuan sebagaimana diungkapkan oleh Abdul Mudjib dalam (Sudarto, 2016) yaitu sebagai proses transinternalisasi pengetahuan dan nilai-nilai ajaran Islam kepada peserta didik melalui upaya pengajaran, pembiasaan, bimbingan, pengasuhan, pengawasan dan pengembagan potensi agar subyek didik mampu memahami, menghayati dan mengamalkan nilai-nilai ajaran Islam di kehidupan sehari-hari guna mencapai keselarasan dan kesempurnaan hidup di dunia dan di akhirat.

Selain itu Majelis ta'lim juga dikatakan sebagai salah satu bentuk alternatif pendidikan Islam nonformal, diselengarakan sebagaimana amanat UU No. 20 Tahun 2003 Tentang Sistem Pendidikan Nasional Pasal 26 menyatakan bahwa, pendidikan nonformal diselanggarakan bagi masyarakat yang memerlukan layanan pendidikan yang berfungsi sebagai pengganti, penambah atau sebagai pelengkap dari pendidikan formal dalam rangka mendukung pendidikan sepanjang hayat. Selain itu majelis ta'lim dapat berfungsi juga sebagai sarana untuk memperdalam pemahaman ilmu agama, serta menjalin hubungan ukhuwah Islamiah dimasyarakat, dengan waktu penyelenggaraannya yang fleksibel.

Majelis ta'lim sebagai lembaga dan wadah penyelenggaraan pendidikan agama Islam nonformal, senantiasa berupaya dalam memberikan bimbingan, pengetahuan dan pemahaman ajaran Islam kepada setiap jama'ah, Sudijono dalam (Djamal, 2017) menjelaskan arti pemahaman sebagai kemampuan yang dimiliki oleh seseorang untuk memahami, mengerti, atau menangkap makna dari sesuatu yang telah di pelajari, dihafal 
atau diingat seperti, tatacara beribadah, bersuci, beradab/akhlak, serta membangun keimanan dan ketakwaan kepada Allah kedalam diri jama'ah, serta membangun hubungan sosial yang baik antara sesama masyarakat.

Untuk mencapai tujuan demikian diperlukan pembelajaran disetiap kegiatan yang dilaksanakan. Pembelajaran sebagaimana di sebutkan oleh (Jamaludin, 2015) merupakan suatu usaha yang dilakukan oleh seorang pendidik/guru untuk mencapai tujuan berupa keampuan tertentu atau usaha yang dilakukan pendidik/guru untuk memperoleh atau meningkatan kemampuan peserta didik/murid. Senada dengan itu sudjana dalam (Saepudin, 2015) mengungkapkan pembelajaran merupakan upaya yang dilakukan secara sadar dan sengaja oleh pendidik untuk membuat peserta didik melakukan kegiatan belajar, dalam rangka menggali pengetahuan. sedangkan menurut. (Aprida Pane, 2017) pembelajaran merupakan proses interaksi antara guru dan peserta didik dalam upaya penyampaian bahan ajar dengan menggunakan strategi, metode dan sumber belajar yang menunjang untuk tercapainya tujuan pembelajaran.

Berdasarkan keterangan diatas dapat di simpulkan, pembelajaran merupkan usaha yang dilakukan secara sadar dan terencana oleh pendidik untuk menciptakan interaksi dua arah melalui proses belajar, pengalaman dan bimbingan untuk mencapai tujuan yang telah ditetapkan.

Sementara itu, di dalam proses kegiatan pembelajaran, tentu ada materi yang harus di sampaikan kepada peserta didik. Yaitu berupa serangkaian bahan-bahan dan sumber bahan ajar yang disampaikan seseorang (pendidik), untuk memenuhi kebutuhan peserta didik guna meningkatkan pengetahuan, pemahaman dan pengalaman belajar. Sudjana dalam (Risha Afandi, 2013) mengatakan materi merupakan bagian terpenting dalam proses pembelajaran guna menentukan hasil dari tujuan belajar. Dalam hal ini materi yang diajarkan yakni berkenan dengan pokok-pokok ajaran Islam diantaranya Akidah, ibadah, akhlak, tasawuf, dan sebagainya. (Mustofa, 2016) dan dalam pengajaran materi tersebut, juga tidak luput dari penggunaan metode sebagai upaya untuk mendukung keberhasilan pembelajaran.

Majelis Ta'lim Ar-Ridho adalah salah satu contoh pendidikan Islam nonformal, yang beralamat di Jl. Raya Puncak Km 70,/ Desa Cipayung Datar Rt/Rw 02/03 Kecamatan Megamendung Kabupaten Bogor. Dalam peraktiknya Majelis Talim ArRidho masih mempertahankan ciri khas pembelajaran pesantren salafiah, baik dari penggunaan sumber belajar, pemilihan materi dan penggunaan metode. kemudian dihadiri oleh jama'ah pria. Adapun Bentuk kegiatan pembelajaran atau pendidikannya sudah diatur dalam peraturan pemerintah No 55 Tahun 2007 pasal 21 ayat 1 yakni Pendidikan Islam Nonformal diselenggarakan dalam bentuk pengajian kitab, majelis ta'lim, pendidikan Al-Quran serta diniyah taklimiyah. Sementara itu kegiatan pendidikan dan pembelajaran yang diselenggarakan pada majelis ta'lim dan pesantren mempunyai kesamaan yakni: pengajian Kitab, pendidikan Al-Quran, pembacaan Shalawat Nabi $S A W$, dan pembacaan Ratib/Dzikir. (Darlis, 2017) 
Mayoritas materi rujukan yang diajarkan masih menggunakan kitab klasik atau kitab kuning yang sudah menjadi ciri khas pesantren. (Thoriqussu'ud, 2012) mengatakan, Kitab merupakan istilah penyebutan sebuah karya yang ditulis pada kertas kuning, menggunakan huruf dan bahasa Arab yang di dalamnya berisikan matan dan syarakh. Hingga saat ini keberadaan kitab kuning masih dijadikan sebagai sumber utama pembelajaran di pesantren dan lembaga pendidikan Islam tradisional saat ini, termasuk majelis ta'lim.

Adapaun kitab-kitab yang dijadikan sumber pembelajaran diantaranya: Fiqh (ibadah), seperti Qurrah Al-Ayn, Minhaj Al-Thalibin, Kifayah Al-Akhyar, Fath Al-Qarib, Kasyifatu As-Saja, Syarah Safinatu An-Najah. Kemudian Kajian Akhlak, Kitab yang diajrkan yakni: Matan/syarah Ta'limulmuta'allim, Akhlak lil Banin, Nasaibul Ibad, Taisirul Khalaq, Makarjmul Akhlak, Nazmul Akhlaq dan sebagainya. Kajian Akidah, Kitab yang diajarkan yakni: kitab Aqidatul Aw'wam, Kitab Tauhid Aqaidul Iman, Kitab Tasawuf Hikam/Syarah, Ihya Ulumuddin, Risalah Muawanah, Bidayatul bidayah, Tanwirul Qulub, dan sebagainya. Kajian Hadist Kitab yang diajarkan:, Arba'in Nawawi, Targib wa Tarhib, Assahihul Bukhari wa Muslim dan sebagainya. Wahid, dkk. dalam (Amrizal, 2016)

Adapun jadwal waktu \& pelaksanaan kegiatan pembelajaran Majelis Ta'lim ArRidho adalah sebagai berikut:

\section{1) Hari Minggu, Malam Senin}

\begin{tabular}{|c|c|c|c|c|}
\hline No & Wktu & Jenis Kegiatan & $\begin{array}{l}\text { Penggunaan } \\
\text { Metode }\end{array}$ & Pengajar/Pembimbing \\
\hline 1 & $\begin{array}{l}19.30- \\
20.00 \\
\text { WIB }\end{array}$ & $\begin{aligned}> & \text { Tawasulan } \\
> & \text { Pembacaan Dzikir } \\
> & \text { Pembacaan Ratib } \\
& \text { Alaydrus }\end{aligned}$ & ○ Pembiasaan & $\begin{array}{l}\text { Ust. Ade Faiz, Ust. } \\
\text { Herlan dan Santri }\end{array}$ \\
\hline 2. & $\begin{array}{l}20.00- \\
20.40 \\
\text { WIB }\end{array}$ & $\begin{aligned}> & \text { Membaca } \\
& \text { Maulid/Shalawat } \\
& \text { Diba'i/ Burdah } \\
> & \text { Pembacaan Do'a }\end{aligned}$ & ○ Pembiasaan & $\begin{array}{l}\text { Ust. Ade Faiz, Ust. } \\
\text { Herlan dan Santri }\end{array}$ \\
\hline 3 & $\begin{array}{l}20.40- \\
21.50 \\
\text { WIB }\end{array}$ & 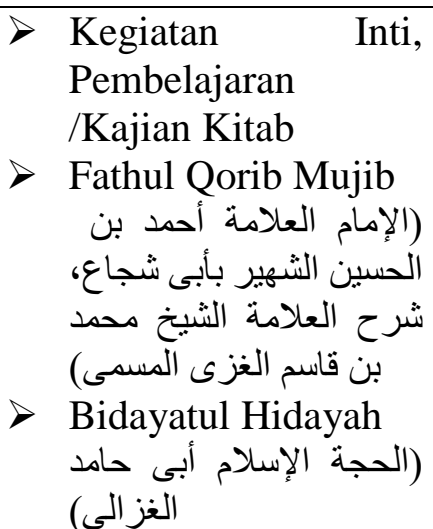 & $\begin{array}{ll}\circ & \text { Pembiasan } \\
\circ & \text { Ceramah } \\
\circ & \text { Teladan } \\
\circ & \text { Bercerita } \\
\circ & \text { Nasehat } \\
\circ & \text { Diskusi } \\
\circ & \text { Demonstrasi }\end{array}$ & $\begin{array}{l}\text { KH. Zaini Husaini } \\
\text { (Aang Deni) }\end{array}$ \\
\hline
\end{tabular}




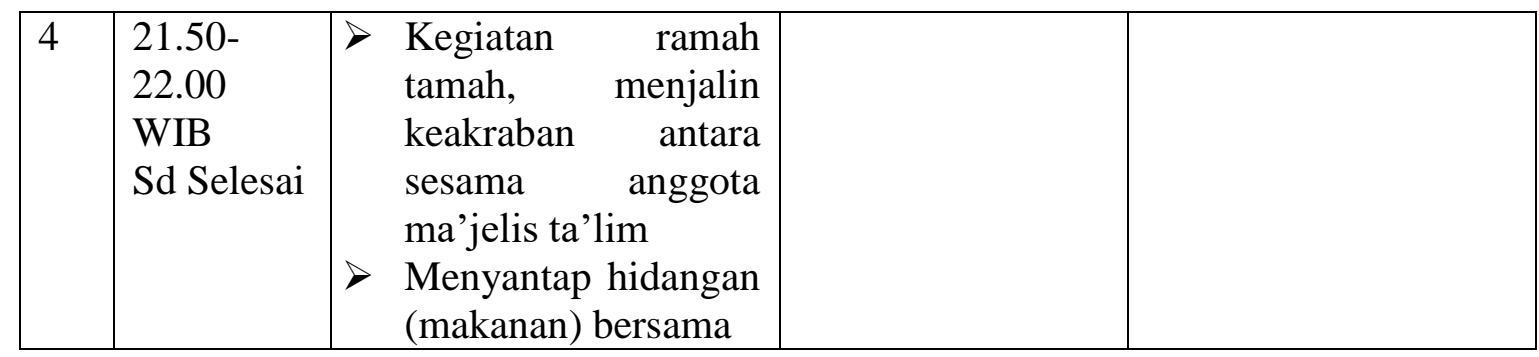

2) Hari Kamis Malam Jum'at

\begin{tabular}{|c|c|c|c|c|}
\hline No & Wktu & Jenis Kegiatan & $\begin{array}{l}\text { Penggunaan } \\
\text { Metode }\end{array}$ & Pengajar/Pembimbing \\
\hline 1 & $\begin{array}{l}19.30- \\
20.00 \\
\text { WIB }\end{array}$ & $\begin{array}{l}>\text { Tawasulan } \\
>\text { Pembacaan Dzikir } \\
>\begin{array}{l}\text { Pembacaan Ratib } \\
\text { Alaydrus }\end{array}\end{array}$ & o Pembiasaan & $\begin{array}{l}\text { Ust. Ade Faiz dan } \\
\text { Santri }\end{array}$ \\
\hline 2. & $\begin{array}{l}20.00- \\
20.40 \\
\text { WIB }\end{array}$ & $\begin{aligned} & \text { Membaca } \\
& \text { Maulid/Shalawat } \\
& \text { Diba'i/ Burdah } \\
&>\text { Pembacaan Do'a }\end{aligned}$ & ○ Pembiasaan & $\begin{array}{l}\text { Ust. Ade Faiz dan } \\
\text { Santri }\end{array}$ \\
\hline 3 & $\begin{array}{l}20.40- \\
21.50 \\
\text { WIB }\end{array}$ & 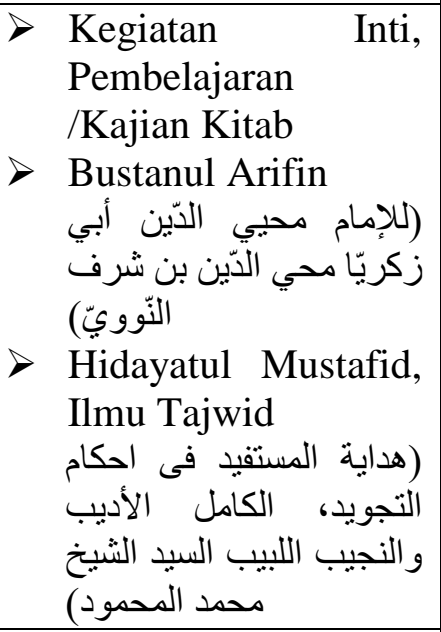 & $\begin{array}{ll} & \text { Pembiasan } \\
\circ & \text { Ceramah } \\
\circ & \text { Teladan } \\
\circ & \text { Bercerita } \\
\circ & \text { Nasehat } \\
\circ & \text { Diskusi } \\
\circ & \text { Demonstrasi }\end{array}$ & $\begin{array}{l}\text { KH. Zaini Husaini } \\
\text { (Aang Deni) }\end{array}$ \\
\hline 4 & $\begin{array}{l}21.50- \\
22.00 \\
\text { WIB } \\
\text { Sd Selesai }\end{array}$ & $\begin{array}{lr}\text { Kegiatan ramah } \\
\text { tamah, menjalin } \\
\text { keakraban antara } \\
\text { sesama anggota } \\
\text { ma'jelis ta'lim } \\
> \\
\text { Menyantap hidangan } \\
\text { (makanan) bersama }\end{array}$ & & \\
\hline
\end{tabular}

Walaupun proses kegiatan majelis ta'lim sudah berjalan sebagai mestinya, akan tetapi apabila hasilnya tidak sesuai dengan tujuan, maka dapat dipastikan bahwa kegiatan tersebut tidak memiliki efek apapun. Hal ini perlu adanya perbaikan dari cara penyampaian guru (ustadz) atau penggunaan metode yang lebih disesuaikan lagi dengan 
materi dan tingkat usia jamaah. Agar pembelajaran mudah terserap oleh jama'ah dan tujuan pembelajaran pun dapat tercapai.

Dari berbagai permasalahan diatas, maka penulis berkeinginan untuk mengangkat penelitian ini untuk mengetahui " Hubungan Antara Proses Pembelajaran di Majelis

Ta'lim Ar-ridho dengan Tingkat Pemahaman Ajaran Islam Pada Masyarakat Desa Cipayung Datar Rt/02 Rw/03 Kecamatan Megamendung Kabupaten Bogor. “

\section{METODOLOGI PENELITIAN}

Penelitian ini menggunakan metode kuantitatif dengan analisis korelasi yaitu untuk medekteksi sejauh mana variabel pada sebuah faktor berkaitan dengan satu atau lebih variabel faktor (Suryabrata, 2013) atau adanya hubungan sebab akibat antara keadaan pertama dan kedua.

Penelitian ini dilaksanakan pada bulan April 2020, bertempat di Majelis Ta'lim Arridho, beralamat di Jl. Raya Puncak Km 70,/ Desa Cipayung Datar Rt/Rw 02/03 Kecamatan Megamendung Kabupaten Bogor. Kegiatan Majelis Ta'lim Ar-Ridho dilaksanakan pada malam hari, yakni hari minggu malam senin dan hari kamis malam jum'at, pukul 19.30 sd 22.00 WIB.

Untuk menentukan jumlah sempel yang diambil, penulis menggunakan pendapat yang dikemukakan oleh Suharsini Arikunto dikutip dari (Agustin, 2017, hal. 58) menyatakan "apabila populasi $<100$, maka sebaiknya diambil seluruhnya sebagai sempel. Jika populasi > 100, minimal diambil antara 10\% - 15\% atau 20\% - 25\%". Senada dengan itu (Suprih Widodo, 2018, hal. 9) mengatakan apabila jumlah populasi penelitian dianggap kecil atau kurang dari 100, maka peneliti dapat mengambil semua anggota populasi untuk dijadikan sempel penelitian. Teknik ini disebut sebagai Boring Samling atau sering disebut teknik sensus. Maka dengan demikian peneliti menyimpulkan, yakni jama'ah Pria yang hadir pada kegiatan majelis ta'lim Ar-ridho seluruhnya dapat dijadikan sempel penelitian sebanyak 50 responden..

Instrumen penelitian yang digunakan dalam penelitian ini adalah angket. Angket merupakan teknik pengumpulan data yang dilakukan dengan cara memberi seperangkat pertanyaan atau pernyataan kepada responden untuk dijawabnya. (Sugiono, 2018) angket disebarkan kepada 50 orang responden. Data yang teah didapatkan kemudian diolah menggunakan uji korelasi menggunakan bantuan program SPSS versi 22 for Windows. Pengujian hipotesis dilakukan pada taraf signifikan 0,05

\section{HASIL PENELITIAN DAN PEMBAHASAN}

Dari perhitungan keseluruhan data angket yang valid, yakni sejumlah 28 pertanyaan terdiri dari 14 pertanyaan variabel X Proses pembelajaran di majelis ta'lim ar-ridho dan 14 pertanyaan variabel Y Tingkat pemahaman ajaran Islam masyarakat. Maka diperoleh presentase nilai rata-rata dari keseluruhan data angket diantaranya adalah: 
Rekapitulasi jawaban angket variabel (X) Proses pembelajaran pada Majelis Ta'lim Ar-ridho dalam kriteria "Sangat Baik". hal ini dapat dilihat dari rata-rata presentase yang diperoleh, yaitu: indikator jawaban dengan sekor 1 (TS) presentase rata-ratanya sebesar $3,43 \%$, kemudian indikator jawaban dengan sekor 2 (RR) presentase rata-ratanya sebesar 3,57\%, kemudian indikator jawaban dengan sekor $3(\mathrm{~S})$ presentase rata-ratanya sebesar $22,00 \%$, kemudian indikator jawaban dengan sekor 4 (SS) presentase rata-ratanya sebesar 71,00 \%. Dengan demikian dapat diketahui bahwa jumlah jawaban terbanyak adalah indikator jawaban dengan sekor 4 (SS) dengan presentase rata-rata sebesar $71,00 \%$. Hal ini dapat dikatakan bahwa proses pembelajaran pada Majelis Ta'lim Arridho berjalan dengan sangat baik.

Sedangkan Rekapitulasi jawaban angket variabel (Y) Tingkat pemahaman ajaran Islam pada masyarakat Desa Cipayung Datar Rt/Rw 02/03 Kecamatan Megamendung Kabupaten Bogor dalam kriteria "Sangat Baik". hal ini dapat dilihat dari rata-rata presentase yang diperoleh, yaitu: indikator jawaban dengan sekor 1 (TS) presentase rataratanya sebesar $6,57 \%$ kemudian indikator jawaban dengan sekor 2 (RR) presentase rataratanya sebesar 7,43\%, kemudian indikator jawaban dengan sekor $3(\mathrm{~S})$ presentase rataratanya sebesar 30,43\%, kemudian indikator jawaban dengan sekor 4 (SS) presentase rata-ratanya sebesar 55,57 \%. Dengan demikian dapat diketahui bahwa jumlah jawaban terbanyak adalah indikator jawaban dengan sekor 4 dengan presentase rata-rata sebesar $55,57 \%$. Hal ini dapat dikatakan bahwa tingkat pemahaman ajaran Islam pada masyarakat desa cipayung datar dikatakan sangat baik.

Adapun validitas pada kedua variabel akan dikemukakan pada tabel berikut:

Validitas variabel $\mathrm{X}$

Proses Pembelajaran Majelis Ta'lim Ar-Ridho

\begin{tabular}{|c|c|c|c|c|}
\hline $\begin{array}{c}\text { Instrumen } \\
\text { Penelitian }\end{array}$ & No & $\boldsymbol{r}$ Tabel & $\boldsymbol{r}$ Hitung & Keterangan \\
\hline \multirow{4}{*}{} & 1 & 0,284 & 0,354 & Valid \\
\cline { 2 - 5 } & 2 & 0,284 & 0,321 & Valid \\
\cline { 2 - 5 } & 3 & 0,284 & 0,420 & Valid \\
\cline { 2 - 5 } & 4 & 0,284 & 0,424 & Valid \\
\cline { 2 - 5 } $\begin{array}{c}\text { Proses } \\
\text { Pembelajaran } \\
\text { Majelis }\end{array}$ & 5 & 0,284 & 0,444 & Valid \\
\cline { 2 - 5 } Ta'lim Ar- & 6 & 0,284 & 0,376 & Valid \\
\cline { 2 - 5 } Ridho & 7 & 0,284 & 0,594 & Valid \\
\cline { 2 - 5 } & 9 & 0,284 & 0,592 & Valid \\
\cline { 2 - 5 } & 10 & 0,284 & 0,511 & Valid \\
\cline { 2 - 5 } & 11 & 0,284 & 0,608 & Valid \\
\cline { 2 - 5 } & 12 & 0,284 & 0,580 & Valid \\
\cline { 2 - 5 } & 13 & 0,284 & 0,677 & Valid \\
\hline
\end{tabular}


\begin{tabular}{|l|c|c|c|c|} 
& 14 & 0,284 & 0,536 & Valid \\
\hline
\end{tabular}

Sumber: Hasil olah data SPSS Versi 22 for windows

Validitas variabel $\mathrm{Y}$

Tingkat Pemahaman Ajaran Islam Masyarakat

\begin{tabular}{|c|c|c|c|c|}
\hline $\begin{array}{c}\text { Instrumen } \\
\text { Penelitian }\end{array}$ & No & $\boldsymbol{r}$ Tabel & $\boldsymbol{r}$ Hitung & Keterangan \\
\hline \multirow{4}{*}{} & 1 & 0,284 & 0,447 & Valid \\
\cline { 2 - 5 } & 2 & 0,284 & 0,312 & Valid \\
\cline { 2 - 5 } & 3 & 0,284 & 0,319 & Valid \\
\cline { 2 - 5 } & 4 & 0,284 & 0,313 & Valid \\
\cline { 2 - 5 } & 5 & 0,284 & 0,472 & Valid \\
\cline { 2 - 5 } Tingkat & 6 & 0,284 & 0,402 & Valid \\
\cline { 2 - 5 } $\begin{array}{c}\text { Ajaran } \\
\text { Islam }\end{array}$ & 7 & 0,284 & 0,316 & Valid \\
\cline { 2 - 5 } Masyarakat & 8 & 0,284 & 0,402 & Valid \\
\cline { 2 - 5 } & 9 & 0,284 & 0,624 & Valid \\
\cline { 2 - 5 } & 10 & 0,284 & 0,620 & Valid \\
\cline { 2 - 5 } & 11 & 0,284 & 0,729 & Valid \\
\cline { 2 - 5 } & 12 & 0,284 & 0,637 & Valid \\
\cline { 2 - 5 } & 13 & 0,284 & 0,624 & Valid \\
\cline { 2 - 5 } & 14 & 0,284 & 0,388 & Valid \\
\hline
\end{tabular}

Sumber: Hasil olah data SPSS Versi 22 for windows

Hasil Uji Reliabilitas

\begin{tabular}{|c|c|}
\hline Variabel & $\begin{array}{c}\text { Cronbach's } \\
\text { Alpha }\end{array}$ \\
\hline $\begin{array}{c}\text { Proses Pembelajaran Majelis Ta'lim Ar- } \\
\text { Ridho }\end{array}$ & 0,762 \\
\hline $\begin{array}{c}\text { Tingkat Pemahaman Ajaran Islam Pada } \\
\text { Masyarakat }\end{array}$ & 0,719 \\
\hline
\end{tabular}

Sumber: Hasil olah data SPSS Versi 22 for windows

Berdasarkan Hasil uji reliabilitas variabel $\mathrm{X}$ dan $\mathrm{Y}$ dapat dilihat perolehan nilai Cronbach's Alpha (Variabel X) 0,726 dan (Variabel Y) 0,719 kedua nilai tersebut melebihi standar nilai koefisien Cronbach's Alpha sebesar 0,60 maka dapat disimpulkan bahwa alat ukur penelitian ini bersifat reliabel.

Setelah melakukan uji validitas dan reliabilitas maka dilanjut untuk melakukan uji normalitas dengan menggunakan SPSS Versi 22 for windows hasil pengujian normalitas dapat dilihat pada tabel berikut: 
Hasil Uji Normalitas

One-Sample Kolmogorov-Smirnov Test

\begin{tabular}{|ll|r|}
\hline & & Unstandardized Residual \\
\hline N & Mean & 50 \\
Normal & Std. Deviation & 0,0000000 \\
Parameters & & 3,47920903 \\
Most Extreme & Absolute & 0,098 \\
Differences & Positive & 0,061 \\
& Negative & $-0,098$ \\
Test Statistic & & 0,098 \\
Asymp. Sig. (2-tailed) & & $0,200^{c, d}$ \\
\hline
\end{tabular}

a. Test distribution is Normal.

b. Calculated from data.

c. Lilliefors Significance Correction.

d. This is a lower bound of the true significance.

Sumber: Hasil olah data SPSS Versi 22 for windows

Berdasarkan data tabel diatas, diiketahui nilai tes statistik adalah 0,098 dengan nilai signifikansi sebesar 0,200 > dari 0,05 sehingga dapat disimpulkan data yang digunakan berdistribusi normal.

Analisis data dalam penelitian ini menggunakan uji Corelation Product Moment yang dilakukan dengan metode statistik Pearson Corellation Product Moment.

Uji korelasi produk momen

\begin{tabular}{|c|c|c|c|}
\hline \multicolumn{4}{|c|}{ Correlations } \\
\hline & & $\begin{array}{c}\text { Proses } \\
\text { pembelajaran } \\
\text { pada Majelis } \\
\text { Ta'lim }\end{array}$ & $\begin{array}{c}\text { Tingkat } \\
\text { pemahaman } \\
\text { Ajaran Islam }\end{array}$ \\
\hline \multirow{3}{*}{$\begin{array}{l}\text { Proses } \\
\text { pembelajaran pada } \\
\text { Majelis Ta'lim }\end{array}$} & \begin{tabular}{|l|} 
Pearson \\
Correlation \\
\end{tabular} & 1 & $0.579^{*}$ \\
\hline & Sig. (2-tailed) & & 0,000 \\
\hline & $\mathrm{N}$ & 50 & 50 \\
\hline \multirow[t]{3}{*}{$\begin{array}{l}\text { Tingkat pemahaman } \\
\text { Ajaran Islam }\end{array}$} & \begin{tabular}{|l|} 
Pearson \\
Correlation \\
\end{tabular} & $0.579^{\star *}$ & 1 \\
\hline & Sig. (2-tailed) & 0,000 & \\
\hline & $\mathrm{N}$ & 50 & 50 \\
\hline
\end{tabular}

Sumber: Hasil olah data SPSS Versi 22 for windows

Berdasarkan output tabel diatas menunjukan bahwa terdapat signifikansi antara proses pembelajaran di majelis ta'lim (x) dengan tingkat pemahaman ajaran Islam (y) (sig $<0,05)$ dengan demikian $\mathrm{H} 0$ ditolak sehingga menunjukan adanya korelasi antara variabel $\mathrm{X}$ dan variabel Y. Lebih lanjut nilai korlasi sebesar 0,579 menunjukan bahwa korelasi 
proses pembelajaran di majelis ta'lim ar-ridho dengan tingkat pemahaman ajaran Islam pada masyarakat Desa Cipayung Datar Rt/02 Rw/03 Kecamatan Megamendung Kabupaten Bogor, memiliki hubungan yang sedang. Pada hasil koefisien korelasi tersebut dapat dipahami bahwa korelasi bersifat positif, artinya semakin baik pembelajaran yang dilakukan guru (Ustadz) dalam mengajar di majelis ta'lim maka akan baik pula tingkat pemahaman masyarakat terhadap ajaran Islam.

Menurut Eisenhower \& Harrison, keberhasilan proses pembelajaran merupakan dampak dari keberhasilan guru dalam menyusun perangkat pembelajaran termasuk menentukan bagaimana aktifitas belajar peserta didik. (Trisakti Handayani, 2020)

\section{SIMPULAN}

Hasil penelitian menunjukan bahwa terdapat korelasi sedang sebesar 0,579 antara proses pembelajaran di majelis ta'lim ar-ridho dengan tingkat pemahaman ajaran Islam pada masyarakat Desa Cipayung Datar Rt/02 Rw/03 Kecamatan Megamendung Kabupaten Bogor, hal ini dapat disimpulkan semakin baik proses pembelajaran yang di terapkan guru (Ustadz) dalam mengajar jama'ah di majelis ta'lim ar-ridho, maka akan baik pula tingkat pemahaman masyarakat terhadap ajaran Islam.

\section{DAFTAR PUSTAKA}

Agustin, M. R. (2017, November). Hubungan Antara Tayangan Ibu Pintar Dengan Sikap Orang Tua Dalam Mendidik Anak. Politikom Indonesia, II(2), 58. Dipetik Agustus 21,2020

Akhmad Alim, M. (2014). Tafsir Pendidikan Islam. Jakarta: AMP Pres.

Amrizal. (2016, Juni). Eksistensi Tradisi Kajian Kitab Kuning Dalam Lingkup Perubahan Sosial (Studi Kasus Di Pesantren Darun Nahdhah, Darel Hikmah, Dan Babussalam). Sosial Budaya, XIII(1), 73-88.

Aprida Pane, M. D. (2017, Desember). Belajar Dan Pembelajaran. Kajian Ilmu Ke Islaman, III(2), 333-352. Dipetik April 21, 2020

Darlis, A. (2017, Januari-Juni). Hakikat Pendidikan Islam: Telaah Antara Hubungan Pendidikan Informal, Nonformal, Dan Formal. Tarbiyah, XXIV(1).

Djamal, S. M. (2017). Penerapan Nilai-Nilai Ajaran Islam dalam Kehidupan Masyarakat Di Desa Garuntungan Kecamatan Kindang Kbupaten Bulukumba. Adabiyah, XVII(2), 161-179. Dipetik Juli 1, 2020

Haddad, H. (2010). Nasihat Agama dan Wasiat Iman. Bandung: Gema Risalah Pres. 
Jamaludin, A. K. (2015). Pembelajaran Prespektif Islam. Bandung: PT Remaja Rosdakarya.

Muhsin MK. (2009). Manajemen Majelis Taklim (1 ed.). Jakarta: Intermasa.

Mustofa, M. A. (2016). Majelis Ta'lim Sebagai Alternatif Pusat Pendidikan Islam (Studi Kasus Pada Majelis Ta'lim Se Kecamatan Natar Lmpung Selatan. Kajian Keislaman dan Kemasyarakatan, I(1).

Noor, J. (2011). Metodologi Penelitian: Skripsi, Tesis, Disertasi, dan Karya Ilmiah (1 ed.). Jakarta: Kencana.

Risha Afandi. (2013, April). Gambaran Pelaksanaan Kegiatan Belajar Majelis Taklim Sebagai Kegiatan Pendidikan Orang Dewasa Di Surau Balerong Monggong. Spektrum PLS, I(1). Dipetik Desember 24, 2019, 16 :29

Saepudin, J. (2015, Agustus 5). Model Pembelajaran Dalam Prespektif Ibnu Khaldun: Resepsi Terhadap Kitab Muqoddimah. Penelitian Pendidikan Agama dan Keagamaan, XIII(2), 222-238. Dipetik April 21, 2020

Sayan Suryana, K. R. (2020, Januari-Juni). Fungsi Komunikasi Pembelajaran Dalam Meningkatkan Pemahaman Siswa Pada Mata Pelajaran Pendidikan Agama Islam Dan Budi Pekerti (Studi Kasus di SMK IPTEK Purwasari Kabupaten Karawang). Wahana Karya Ilmiah_Pascasarjana (S2) PAI Unsika, IV(1), 590-602. Dipetik Juli 1,2020

Sudarto. (2016). Filsafat Pendidikan Islam (1 ed.). Yogyakarta: Deepublish. Dipetik Maret 2016

Sugiono. (2018). Metode Penelitian Pendidikan (Pendekatan Kuantitatif, Kualitatif, dan $R \& D)$. Bandung: Alfabeta.

Suprih Widodo, P. R. (2018). Analisis Data Kuantitatif Dalam Penelitian Pendidikan. Bandung: Royyan Press.

Suryabrata, S. (2013). Metodologi Penelitian (2 ed.). Jakarta: Rajawali Pers.

Thoriqussu'ud, M. (2012). Model-Model Pengembangan Kajian Kitab Kuning Di Pondok Pesantren. Ilmu Tarbiyah At-Tajdid, I(2).

Trisakti Handayani, H. S. (2020). Korelasi nilai RPP dengan nilai PPL Mahasiswa pendidikan profesi guru di daerah khusus. Pendidikan Profesi Guru, I(1), 69. 